\title{
The effects of iodoprophylaxis on thyroid volume and nodular size during pregnancy in an iodine-sufficient area
}

Susana Pérez Naranjo, Ángel Merchante Alfaro, Olalla Rubio Puchol, Pablo Abellán Galiana , Pilar Cubells Cascales, Roser Querol Ripoll. Departamaent of Endocrinology and Nutrition. University General Hospital of Castellon.

\section{INTRODUCTION}

- During pregnancy, the thyroid volume (TV) increases by $20 \%$ to $35 \%$ in areas with iodine deficiency. In iodine-sufficient countries, while some studies showed an increase in TV by $10-15 \%$, others did not observe any change in TV during pregnancy. Thyroid nodules may be present in up to $15-35 \%$ of pregnant women in areas with moderate iodine deficiency. However, in areas with iodine-sufficient, thyroid nodules were investigated in a few number of studies

\section{OBJETIVE}

- We aimed to evaluate the TV and prevalence of thyroid nodules during pregnancy in an iodine-sufficient area

\section{SUBJECTS AND METHODS}

- We prospectively followed, in an iodine-sufficient area, 205 pregnant women (mean age $32.98 \pm 5.01$ years) in the first-trimester (1T) and 65 control group of non-pregnant healthy women matched by age and body mass index. Pregnant women were supplemented with $200 \mu \mathrm{g}$ of iodine daily. We evaluated thyroid hormone levels, ultrasound examination of thyroid and urine iodine concentration (UIC) in the 1T, and thyroid nodules in the third-trimester (3T).

\section{RESULTS}

-The pregnant women group showed: median UIC $193 \mu \mathrm{g} / \mathrm{l}$, mean serum TSH $3.44 \pm 1.96 \mathrm{mUI} / \mathrm{l}$ and mean TV $9.17 \pm 3.30$ $\mathrm{ml}$ in the 1T. Twenty-two women had thyroid nodules on thyroid ultrasonography at the 1T. The number of nodules and the maximum diameter of dominant nodule did not change in the 3T $(11.2 \pm 4.2 \mathrm{ml}$ against $10.2 \pm 4.2 \mathrm{ml}$ in the $1 \mathrm{~T})$. The control group of non-pregnant women showed: median UIC $143 \mu \mathrm{g} / \mathrm{l}$, mean serum TSH $2.75 \pm 2.02 \mathrm{mUI} / \mathrm{l}$ and mean TV $8.07 \pm 2.20 \mathrm{ml}$. Ten women had thyroid nodules on thyroid ultrasonography $(15.38 \%)$.

\begin{tabular}{|c|c|c|}
\hline VARIABLES & NON PREGNANT WOMEN & PREGNANT WOMEN \\
\hline $\mathrm{N}$ & 65 & 205 \\
\hline AGE (years) $($ mean \pm SD) & $32,40 \pm 6,3$ & $32,98 \pm 5,01$ \\
\hline $\operatorname{BMI}\left(\mathrm{kg} / \mathrm{m}^{2}\right)(\operatorname{mean} \pm \mathrm{SD})$ & $22,98 \pm 1,2$ & $23,54 \pm 2,10$ \\
\hline Goiter (\%) & $0 \%$ & $2,92 \%$ \\
\hline $\mathrm{VT}(\mathrm{ml})(\mathrm{mean} \pm \mathrm{SD})$ & $8,07 \pm 2,2$ & $9,17 \pm 3,3^{*}$ \\
\hline UIC(ug/l) (median) & 143,6 & 193,4 * \\
\hline $\mathrm{TSH}(\mathrm{mUI} / \mathrm{l})(\operatorname{mean} \pm \mathrm{SD})$ & $2,75 \pm 2,02$ & $3,44 \pm 1,96$ * \\
\hline $\mathrm{fT} 4(\mathrm{ng} / \mathrm{dl})(\operatorname{mean} \pm \mathrm{SD})$ & $0,706 \pm 0,15$ & $0,710 \pm 0,16$ \\
\hline Number nodules $\mathrm{n}(\%)$ & $10(15,38 \%)$ & $22(10,73 \%)$ \\
\hline Number nodules $2-5 \mathrm{~mm}$ & 5 & 9 \\
\hline Number nodules $6-10 \mathrm{~mm}$ & 3 & 5 \\
\hline Number nodules $>10 \mathrm{~mm}$ & 2 & 8 \\
\hline Consumption iodized salt( \%) & $44,61 \%$ & $61,95 \%$ * \\
\hline
\end{tabular}

Table 1. Descriptive analysis of the variables in non-pregnant women and pregnant women in an iodine- sufficient area

\section{CONCLUSIONS} - In an iodine-sufficient area as Spain, during pregnancy, the TV increase by $13.63 \%$ and is associated with urine iodine
concentration. Thyroid nodules were present in $10.73 \%$ of pregnant women and did not increased in the $3 \mathrm{~T}$. 